\title{
Biological characteristics of Telenomus alecto and Trichogramma galloi reared on eggs of the sugarcane borer Diatraea flavipennella
}

\author{
Nivia da Silva Dias-Pini ${ }^{1}$, Sônia Maria Forti Broglio², Simone da Silva Costa $^{2}$, \\ Jakeline Maria dos Santos $^{2} \&$ Elio Cesar Guzzo 3
}

${ }^{1}$ Embrapa Agroindústria Tropical, Rua Dra Sara Mesquita, 2270, Planalto do Pici, 60511-110 Fortaleza-CE, Brasil. nivia.dias@embrapa.br; ${ }^{2}$ Centro de Ciências Agrárias, Universidade Federal de Alagoas, Rodovia BR 104, km 85, 57100-000 Maceió-AL, Brasil. soniamfbroglio@gmail.com simone_costa85@hotmail.com; jackbilu@hotmail.com

${ }^{3}$ Embrapa Tabuleiros Costeiros, Unidade de Execução de Pesquisa e Desenvolvimento de Alagoas, Caixa Postal 2013, 57061-970, Maceió-AL, Brasil. elio.guzzo@embrapa.br

\begin{abstract}
Biological characteristics of Telenomus alecto and Trichogramma galloi reared on eggs of the sugarcane borer Diatraea flavipennella. Diatraea flavipennella (Box) (Lepidoptera, Crambidae) is one of the most destructive pests in sugarcane plantations in the Northeast Region of Brazil. Developmental characteristics and parasitism potential of the egg parasitoids Telenomus alecto Crawford (Hymenoptera, Scelionidae) and Trichogramma galloi Zucchi (Hymenoptera, Trichogrammatidae) were compared with the aim of selecting a suitable species for biological control of D. flavipennella. Both T. alecto and T. galloi developed well and were readily adapted to $D$. flavipennella eggs as host. Although, T. galloi presented higher viability, with more adults emerging per host egg and higher sex ratio, the developmental period (egg-adult) was shorter in T. alecto and female longevity was extended. In addition, T. alecto exhibited significant higher levels of parasitism during the first three days after emergence than T. galloi. Thus, both parasitoids studied here offer considerable potential for the control of $D$. flavipennella in sugarcane.
\end{abstract}

KEYWORDS. Biological control; egg parasitoid; parasitism capacity.

RESUMO. Características biológicas de Telenomus alecto e Trichogramma galloi em ovos da broca da cana-de-açúcar Diatraea flavipennella. Diatraea flavipennella (Box) (Lepidoptera, Crambidae) é considerada uma das principais pragas da cana-de-açúcar nos canaviais da região nordeste do Brasil. As características biológicas e o potencial de parasitismo dos parasitoides de ovos Telenomus alecto Crawford (Hymenoptera, Scelionidae) e Trichogramma galloi Zucchi (Hymenoptera, Trichogrammatidae) foram comparados com o objetivo de selecionar aespécie mais adequada para utilização no controle biológico de $D$. flavipennella. Tanto T. alecto como T. galloi desenvolveram-se e mostraram-se adaptadas aos ovos de D. flavipennella. Embora T. galloi tenha apresentado maior viabilidade, com maior número de adultos emergidos/ovo do hospedeiro e maior predominância de fêmeas, a duração do período de desenvolvimento (ovo-adulto) foi menor em T. Alecto, e suas fêmeas foram mais longevas. Além disso, T. alecto apresentou taxas de parasitismo mais elevadas durante os primeiros três dias após a emergência, em comparação com $T$. galloi. Ambos os parasitoides estudados apresentam potencial para o controle de D. flavipennella em cana de açúcar.

PALAVRAS-CHAVE. Capacidade de parasitismo; controle biológico; parasitoide de ovos.

Brazil is the world's largest producer and exporter of sugarcane with an estimated 625 million tones of raw material being processed in the sugar mills and ethanol distilleries during the 2010/2011 season. In the state of Alagoas, about 438,570 hectares are planted with sugarcane, making this state the largest producer in the Northeast Region of Brazil with an estimated harvest of 26.75 million tons of raw material in the 2010/2011 season (CONAB 2011).

Each year, the limits of the areas of sugarcane have expanded in Brazil, leading to substantial increase of the risk of pest infestation. In this context, crambid moths of the genus Diatraea (Lepidoptera, Crambidae) are of particular importance because of the frequency with which they occur and the damage that they cause (Botelho et al. 1999). Two species of this genus of borers, namely, Diatraea saccharalis Fabricius,
1974 and Diatraea flavipennella (Box, 1931), are considered the principal sugarcane pests in Brazil (Cheavegatti-Gianotto et al. 2011). While the former species is widely distributed in sugarcane-producing areas throughout the country, the latter is restricted to Alagoas and surrounding states in the Northeast Region (Freitas et al. 2006).

The biological control of Diatraea spp. typically involves Cotesia flavipes Cameron, 1891 (Hymenoptera, Braconidae), a larval parasitoid imported from Asia in the 1970's. Although this wasp has a relatively low production cost and is capable of providing an effective control of sugarcane borers, application of an egg parasitoid would be more efficient since the egg stage represents a key factor in the population increase of this pest (Botelho et al. 1999). In addition, identifying native parasitoid species that could be effective against many 
pests is always desirable instead of importing exotic enemies for biological control (Wajnberg \& Hassan 1994), which reinforces the importance of this kind of work.

Thus, the aim of the present study was, therefore, to evaluate and compare the developmental characteristics and parasitism potential of the egg parasitoids Telenomus alecto Crawford, 1914 (Hymenoptera, Scelionidae) and Trichogramma galloi Zucchi, 1988 (Hymenoptera, Trichogrammatidae), which occur naturally in sugarcane plantations in the Northeast Region of Brazil, in order to select the most suitable species for the biological control of $D$. flavipennella.

Specimens of T. alecto and T. galloi were isolated from eggs of $D$. flavipennella collected from sugarcane plantations in the state of Alagoas $\left(12^{\circ} 40^{\prime} \mathrm{S}, 39^{\circ} 06^{\prime} \mathrm{W}, 127 \mathrm{~m}\right.$ of altitude). The parasitoids were reared for several generations in laboratory at $25 \pm$ $2^{\circ} \mathrm{C}, 70 \pm 10 \% \mathrm{RH}$ and $14: 10 \mathrm{~h}$ (L:D), on D. saccharalis eggs.

Newly-emerged females of T. alecto and T. galloi were transferred individually to glass tubes ( $75 \times 12 \mathrm{~mm}$; 30 tubes per species), each of which contained a mass of $D$. flavipennella eggs (comprising about 30 eggs aged 0 to $12 \mathrm{~h}$ ) and one drop of honey as food source. Parasitism was observed for three days with the host egg masses being replaced daily. The number of parasitized eggs was evaluated daily. The following characteristics of the parasitoids were determined: percentage of emergence (viability), developmental period (egg-adult), number of adults emerged per host egg, sex ratio, and longevity of emerged females.

The experiments followed a completely randomized design, considering two treatments (T. alecto and T. galloi) with 30 replicates each and one female per replicate. Differences of biological parameters between the parasitoids were determined using the F test $(\alpha=0.05)$. Statistical analyses were performed using SAS software (SAS Institute 2000). Data relating to viability and sex ratio were subjected to respective transformations of $\operatorname{arcsine}(\mathrm{x} / 100)^{0.5}$ and $\operatorname{arcsine}(\mathrm{x}+0.5)^{0.5}$, respectively. Within-species comparisons of the numbers of parasitized eggs on each of the first three days after parasitoid emergence, and between-species comparisons of the numbers of eggs parasitized in the same day after parasitoid emergence and of the total numbers of eggs parasitized over the three-day period, were performed using factorial ANOVA, with days and parasitoid species as factors, and the means were separated by Tukey's test $(\alpha=0.05)$.

The mean values of viability, developmental time, female longevity, number of adults emerged per host egg and sex ratio for the two parasitoid species were statistically different (Table I). T. alecto presented viability significantly lower $\left(F_{1.24}=4.90, P<0.05\right)$ than $T$. galloi $(70.17 \pm 2.73 \%$ and $81.94 \pm 4.79 \%$, respectively). Thus, $T$. galloi presented an egg-adult developmental time (14.36 \pm 1.73 days) longer than T. alecto $(12.37 \pm 1.70$ days $)\left(F_{1.24}=1,036.97, P<0.01\right)$. The number of adults that emerged per egg was also significantly higher $\left(F_{1.24}=92.41, P<0.01\right)$ for T. galloi $(2.40 \pm 0.03$ adults/egg) than for T. alecto (1.00 \pm 0.02 adult/egg).

Significant differences $\left(F_{1.24}=41.46, P<0.01\right)$ were observed between $T$. alecto and $T$. galloi regarding the sex ra- tios $(0.71 \pm 0.04$ and $0.88 \pm 0.02$, respectively $)$. Females of T. alecto exhibited an extended longevity (13.76 \pm 6.97 days $)$ in comparison with those of $T$. galloi $(9.60 \pm 2.57$ days $)\left(F_{1.24}=\right.$ $16.55, P<0.01)$.

The numbers of $D$. flavipennella eggs parasitized by $T$. alecto were significantly higher on the first $\left(F_{1.58}=4.04, P<\right.$ $0.05)$, second $\left(F_{1.58}=8.39, P<0.01\right)$ and third $\left(F_{1.58}=9.03, P\right.$ $<0.01)$ days after emergence than the equivalent values for T. galloi (Table II). Consequently, the total number of eggs parasitized by $T$. alecto over the three-day period (47.83 \pm 3.27 eggs $)$ was also significantly higher $\left(F_{1.58}=45.47, P<\right.$ $0.01)$ than by $T$. galloi $(35.77 \pm 2.97$ eggs $)$. Among the three days of parasitism, the number of parasitized eggs was significantly higher in the first day for both T. alecto $\left(F_{2.87}=\right.$ 39.34, $P<0.01)$ and T. galloi $\left(F_{2.87}=42.55, P<0.01\right)$.

The relatively high viability of $T$. alecto and $T$. galloi observed in the present study indicates that eggs of $D$. flavipennella were a suitable host for the two parasitoid species. The duration of the period from egg to adult for both parasitoids was much longer than that reported by PereiraBarros et al. (2005) for T. galloi $(9.46 \pm 0.7$ days) reared in eggs of $D$. saccharalis, which is closely related to $D$. flavipennella.

The number of $T$. alecto and $T$. galloi adults emerged per egg is similar to the value reported for T. alecto $(2.29 \pm 0.43$ adults/host egg) in D. saccharalis (Pereira-Barros et al. 2005), and of 1 adult/host egg observed by Bueno et al. (2008) for Telenomus remus Nixon, 1937 (Hymenoptera, Scelionidae) in Spodoptera frugiperda (Smith, 1797) (Lepidoptera, Noctuidae) eggs. The significant differences between species observed in the present study may be justified by the larger body size of $T$. alecto in relation to $T$. galloi.

Despite the significant differences observed in this study, the sex ratios for T. alecto and T. galloi were higher than 0.7 . The result obtained for $T$. galloi differs considerably from those of Pereira-Barros et al. (2005), who reported sex ratio of 0.64 for T. galloi in D. saccharalis eggs, and of Bueno et al. (2008), who obtained $0.59 \pm 0.04$ for $T$. remus in $S$. frugiperda eggs. A high female-male ratio can be beneficial in biological control programs because males do not contribute to the reduction of the pest population by parasitism (Amaya Navarro 1998) and few males can mate many females. The sex ratios recorded in this study can be related to the high suitability of $D$. flavipennella eggs to the wasps.

Female longevity also represents an important factor in the selection of parasitoid species for biological control programs because parasitoids that live longer can engage in parasitism in the field for longer period and, hence, be more efficient. In the present study, females of T. alecto exhibited an extended longevity than T. galloi.

Different parasitism potentials among parasitoid species have been reported in several studies (Beserra \& Parra 2004; Dias et al. 2008, 2010; Molina et al. 2005; Nava et al. 2007) and represent a useful parameter for species selection. $T$. alecto occurs in sugarcane plantations in various countries in South and Central America (Bin \& Johnson 1982; Cueva 
Table I. Biological parameters (mean $\pm \mathrm{SE})$ of Telenomus alecto and Trichogramma galloi in Diatraea flavipennella eggs $\left(25.0 \pm 2{ }^{\circ} \mathrm{C}, 70 \pm 10 \% \mathrm{RH}\right.$, 14:10 h L:D).

\begin{tabular}{|c|c|c|c|c|c|}
\hline \multirow{2}{*}{ Parasitoid } & \multicolumn{2}{|c|}{ Egg-adult period $^{\mathrm{a}}$} & \multicolumn{3}{|c|}{ Adult stage $^{a}$} \\
\hline & Viability $(\%)^{b}$ & Duration (days) & Adults/host egg & Female longevity (days) & Sex ratio ${ }^{c}$ \\
\hline Telenomus alecto & $70.17 \pm 2.73 b$ & $12.37 \pm 1.70 \mathrm{~b}$ & $1.00 \pm 0.02 \mathrm{~b}$ & $13.76 \pm 6.97 \mathrm{a}$ & $0.71 \pm 0.04 \mathrm{~b}$ \\
\hline Trichogramma galloi & $81.94 \pm 4.79 \mathrm{a}$ & $14.36 \pm 1.73 \mathrm{a}$ & $2.40 \pm 0.03 \mathrm{a}$ & $9.60 \pm 2.57 \mathrm{~b}$ & $0.88 \pm 0.02 \mathrm{a}$ \\
\hline
\end{tabular}

a Within each column, mean values followed by the same letter are not significantly different ( $\mathrm{F}$ test: $\mathrm{P} \leqslant 0.05)$.

${ }^{\mathrm{b}}$ Original data were transformed according to $\arcsin (\mathrm{x} / 100)^{0.5}$ prior to analysis.

${ }^{c}$ Original data were transformed according to $\arcsin (\mathrm{x}+0.5)^{0.5}$ prior to analysis.

Table II. Daily and total parasitisation (mean \pm SE) of Diatraea flavipennella eggs by Telenomus alecto and Trichogramma galloi during first three days after emergence of the egg parasitoid $\left(25.0 \pm 2^{\circ} \mathrm{C}, 70 \pm 10 \% \mathrm{RH}, 14: 10 \mathrm{~h} \mathrm{~L}: \mathrm{D}\right)$.

\begin{tabular}{lllc}
\hline \multirow{2}{*}{ Parasitoid } & \multicolumn{2}{c}{ Number of parasitized eggs ${ }^{\mathrm{a}}$} \\
\cline { 2 - 5 } & $\begin{array}{c}\text { During } 1^{\text {st }} \text { day } \\
\text { after emergence }\end{array}$ & $\begin{array}{c}\text { During 2 } 2^{\text {nd }} \text { day } \\
\text { after emergence }\end{array}$ & $\begin{array}{c}\text { During } 3^{\text {rd }} \text { day } \\
\text { after emergence }\end{array}$ \\
\hline Telenomus alecto & $23.67 \pm 1.34 \mathrm{aA}$ & $14.90 \pm 1.17 \mathrm{aB}$ & $\begin{array}{c}\text { Total for the } \\
\text { three-day period }\end{array}$ \\
Trichogramma galloi & $19.80 \pm 1.38 \mathrm{bA}$ & $10.27 \pm 1.09 \mathrm{bB}$ & $57.83 \pm 3.27 \mathrm{a}$ \\
\hline
\end{tabular}

${ }^{a}$ Within each column, mean values followed by the same lower case letter are not significantly different $(\mathrm{F}$ test: $\mathrm{P} \leqslant 0.05)$; Within each row, mean values followed by the same upper case letter are not significantly different (Tukey's test: $\mathrm{P} \leqslant 0.01$ ).

1979; Lima Filho et al. 1979; Souza 1961; Terán 1980, Dias et al. 2011), where this wasp is known to parasitize eggs of D. saccharalis and Diatraea rufescens Box, 1931.

The present study demonstrated that eggs of $D$. flavipennella are efficiently parasitized by T. alecto and $T$. galloi, and that both parasitoids exhibit high viability in the host. T. alecto exhibits shorter development time (egg-adult) and extended longevity of females than $T$. galloi, but have less adults emerged per host egg. These results indicate that both, T. alecto and T. galloi have great potential for the control of $D$. flavipennella in sugarcane.

\section{ACKNOWLEDGEMENTS}

The authors are grateful to the Conselho Nacional de Desenvolvimento Científico e Tecnológico (CNPq) and to the Fundação de Amparo à Pesquisa do Estado de Alagoas (FAPEAL), for financial support.

\section{REFERENCES}

Amaya Navarro, M. 1998. El Trichogramma spp. producción, uso y manejo en Colombia. Guadalajara de Buga, Impresos Técnicos Litográficos, $176 \mathrm{p}$

Beserra, E. B. \& J. R. P. Parra. 2004. Biologia e parasitismo de Trichogramma atopovirilia Oatman \& Platner e Trichogramma pretiosum Riley (Hymenoptera, Trichogrammatidae) em ovos de Spodoptera frugiperda (J. E. Smith) (Lepidoptera, Noctuidae). Revista Brasileira de Entomologia 48: 119-126.

Bin, F. \& N. F. Johnson. 1982. Potential of Telenominae in biocontrol with egg parasitoids (Hym., Scelionidae), p. 275-287. In: INRA Publ. (ed.). Les Trichogrammes. Antibes (France), 20-23 avril 1982. Ed. INRA Publ., 1982 (Les Colloques de 1'INRA, n"9).

Botelho, P. S. M.; J. R. P. Parra; J. F. das Chagas-Neto \& C. P. B. Oliveira. 1999. Associação do parasitóide de ovos Trichogramma galloi Zucchi (Hymenoptera: Trichogrammatidae) e do parasitóide larval Cotesia flavipes (Cam.) (Hymenoptera: Braconidae) no controle de Diatraea saccharalis, (Fabr.) (Lepidoptera: Crambidae) em cana-de-açúcar. Anais da Sociedade Entomológica do Brasil 28: 491-496.

Bueno, R. C. O. de F.; T. R. Carneiro; D. Pratissoli; A. de F. Bueno; O. A. Fernandes. 2008. Biology and thermal requirements of Telenomus remus reared on fall armyworm Spodoptera frugiperda eggs. Ciência Rural 38: $1-6$.

Cheavegatti-Gianotto, A.; H. M. C. de Abreu; P. Arruda; J. C. Bespalhok Filho; W. L. Burnquist; S. Creste; L. di Ciero; J. A. Ferro; A. V. de O. Figueira; T. de S. Filgueiras; M. de F. Grossi-de-Sá; E. C. Guzzo; H. P. Hoffmann; M. G. de A. Landell; N. Macedo; S. Matsuoka; F. de C. Reinach; E. Romano; W. J. da Silva; M. de C. Silva Filho \& E. C.Ulian. 2011. Sugarcane (Saccharum X officinarum): A reference study for the regulation of genetically modified cultivars in Brazil. Tropical Plant Biology 4: 62-89.

CONAB. 2011. Acompanhamento da Safra Brasileira, Cana-de-Açúcar, Safra 2010/2011, Terceiro Levantamento, janeiro 2011, Companhia Nacional de Abastecimento, Brasília. Available from: http:// www.conab.gov.br (accessed 8 Mach 2012).

Cueva, C. M. A. 1979. Estudio preliminar de las poblaciones de huevos de Diatraea saccharalis (F.) y sus parasitos naturales en la caña de azúcar. Revista Peruana de Entomología 22: 25-28.

Dias, N. da S.; J. R. P. Parra \& T. C. da C. Lima. 2008. Seleção de hospedeiro alternativo para três espécies de tricogramatídeos neotropicais. Pesquisa Agropecuária Brasileira 43: 1467-1473.

Dias, N. da S.; J. R. P. Parra \& C. T. dos S. Dias. 2010. Tabela de vida de fertilidade de três espécies neotropicais de Trichogrammatidae em ovos de hospedeiros alternativos como critério de seleção hospedeira. Revista Brasileira de Entomologia 54: 120-124.

Dias, N. da S.; S. M. F. Broglio-Micheletti; N. R. de M. Farias; S. S. da Costa; J. M. dos Santos; D. O. P. Lopes \& V. A. Costa. 2011. Ocorrência de Telenomus alecto Crawford, 1914 (Hymenoptera: Scelionidae) em ovos de Diatraea spp. (Lepidoptera: Crambidae) em cana-de-açúcar no estado de Alagoas, Brasil. Idesia 29: 95-97.

Freitas, M. do R. T.; A. P. P. da Fonseca; E. L. da Silva; A. L. Mendonça; C. E. da Silva; A. L. Mendonça; R. R. do Nascimento \& A. E. G. Sant'Ana. 2006. The predominance of Diatraea flavipennella (Lepidoptera: Crambidae) in sugar cane fields in the State of Alagoas, Brazil. Florida Entomologist 89: 539-540.

Lima-Filho, M.; G. M. Riscado \& J. T. Barbosa. 1979. Comportamento da broca da cana-de-açúcar, Diatraea spp. no estado do Rio de Janeiro, no triênio 1975-77. Anais da Sociedade Entomológica do Brasil 8: 257-280. 
Molina, R. M. S.; V. Fronza \& J. R. P. Parra. 2005. Seleção de Trichogramma spp., para o controle de Ecdytolopha aurantiana, com base na biologia e exigências térmicas. Revista Brasileira de Entomologia 49: 152158

Nava, D. E.; K. M. Takahashi \& J. R. P. Parra. 2007. Linhagens de Trichogramma e Trichogrammatoidea para controle de Stenoma catenifer. Pesquisa Agropecuária Brasileira 42: 9-16.

Pereira-Barros, J. L.; S. M. F. Broglio-Micheletti; A. J. N. dos Santos; L. W. T. de Carvalho; L. H. T. de Carvalho \& C. J. T. de Oliveira. 2005. Aspectos biológicos de Trichogramma galloi Zucchi, 1988 (Hymenoptera: Trichogrammatidae) criados em ovos de Diatraea saccharalis
(Fabricius, 1794) (Lepidoptera: Crambidae). Ciência eAgrotecnologia 29: $714-718$.

SAS Institute. 2000. SAS software: user's guide: version 8.2. Cary: SAS Institute, $291 \mathrm{p}$.

Souza, H. D. 1961. Dois parasitos dos ovos da broca da cana, Diatraea saccharalis (Fabr., 1794). Divulgação Agronômica Shell 3: 1-5.

Terán, B. J. 1980. Lista preliminar de Hymenoptera parasitos de otros insectos en Venezuela. Revista de la Facultad de Agronomía 11: 283 389 .

Wajnberg, E. \& S. A. Hassan. 1994. Biological control with egg parasitoids. Wallingford, CAB International, $304 \mathrm{p}$. 